\title{
A carpenter's hypothenar hammer syndrome
}

\author{
Pietro Giovanni di Summa, ${ }^{1}$ Adrien Yvon, ${ }^{2}$ Wassim Raffoul, ${ }^{1}$ Christof Bollmann ${ }^{1}$
}

${ }^{1}$ Department of Plastic, Reconstructive \& Hand Surgery, University Hospital of Lausanne (CHUV), Lausanne, VD, Switzerland

${ }^{2}$ School of Medicine, The University of Manchester, Manchester, UK

\section{Correspondence to} Adrien Yvon,

adrienyvon@doctors.org.uk

Accepted 7 June 2014

\section{DESCRIPTION}

A 34-year-old man, right-handed, smoker, presented to A\&E with a 2-month history of pain, numbness and cold sensitivity in the fourth and fifth digits of his right hand. He had not suffered from any recent trauma; his usual activity was carpentry. There was no history of Raynaud's disease, connective tissue disorders, vasculitis or thromboangiitis. Mild coldness and pain was present at the fingertips, which were tender and sensitive to touch, with an increased capillary refill time ( $>2 \mathrm{~s}$ ). Allen's test was positive. Ultrasound showed a thrombosed ulnar artery aneurysm (figure 1A) suggesting a hypothenar hammer syndrome (HHS).

After Guyon's canal, the superficial branch of the ulnar artery is protected by scant overlying tissue: with repetitive blunt occupational traumas, this vascular segment can be compressed against the hamate bone and its hook. ${ }^{1}$ Arterial wall damage may lead to aneurysm formation (figure 1B, C), with or without vessel thrombosis, and to microemboli that cause digital ischaemia. Raynaud's disease is a common differential diagnosis, but the main distinguishing features of HHS are a male preponderance, occupation (vibration in Raynaud's vs blunt trauma in HHS), a positive Allen's test (negative in Raynaud's) and the absence of a hyperaemic flush phase. ${ }^{2}$

After smoking cessation and antiplatelet therapy, surgical aneurysm resection with end-to-end anastomosis was performed (figure 1D). Postoperatively symptoms resolved, with confirmed artery patency by ultrasound colour Doppler at 6-month follow-up.

\section{Learning points}

Education of patients' work practices is important when they are known manual labourers, and early detection through occupational screening could be useful.

- Ultrasound is an appropriate investigation to diagnose hypothenar hammer syndrome when typical symptoms are present.

- Surgical resection of the aneurysm and ulnar artery end-to-end anastomosis is an effective treatment option to remove the emboli source and relieve ulnar nerve compression.

\section{Competing interests None.}

Patient consent Obtained.

Provenance and peer review Not commissioned; externally peer reviewed.

\section{REFERENCES}

1 Ablett CT, Hackett LA. Hypothenar hammer syndrome: case reports and brief review. Clin Med Res 2008:6:3-8.

2 Spencer-Green G, Morgan GJ, Brown L, et al. Hypothenar hammer syndrome: an occupational cause of Raynaud's phenomenon. J Rheumatol 1987;14:1048-51. \\ -.}

To cite: di Summa $P G$ Yvon A, Raffoul W, et al. BMJ Case Rep Published online: [please include Day Month Year] doi:10.1136/ bcr-2014-204779
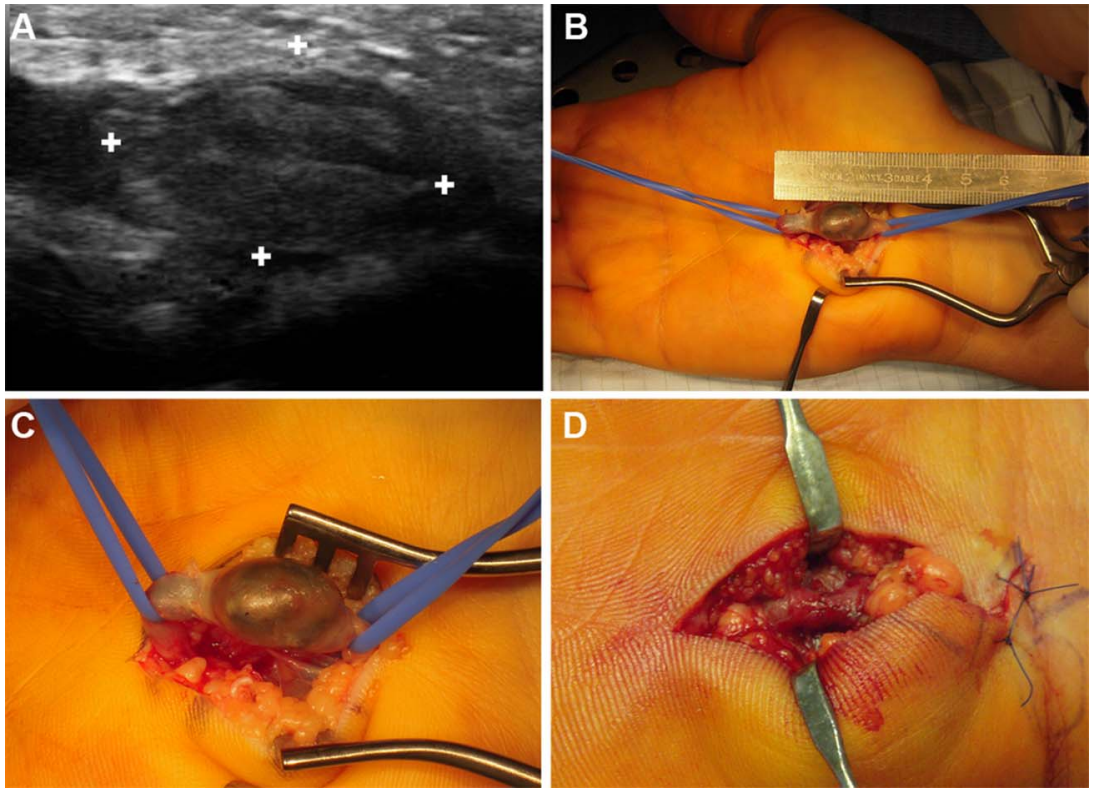

Figure 1 (A) Doppler ultrasound showing an ulnar artery aneurysm. (B and C) Intraoperative photographs of the ulnar artery aneurysm, measuring $1.5 \mathrm{~cm}$ in length. (D) Intraoperative photograph of the end-to-end ulnar artery anastomosis following resection of the aneurysm. 


\section{Images in...}

Copyright 2014 BMJ Publishing Group. All rights reserved. For permission to reuse any of this content visit http://group.bmj.com/group/rights-licensing/permissions.

BMJ Case Report Fellows may re-use this article for personal use and teaching without any further permission.

Become a Fellow of BMJ Case Reports today and you can:

- Submit as many cases as you like

- Enjoy fast sympathetic peer review and rapid publication of accepted articles

- Access all the published articles

- Re-use any of the published material for personal use and teaching without further permission

For information on Institutional Fellowships contact consortiasales@bmjgroup.com

Visit casereports.bmj.com for more articles like this and to become a Fellow 